\title{
Pengaruh Model Pembelajaran Training Inquiry Terhadap Hasil Belajar Pada Pokok Bahasan Kalor Siswa SMP Negeri 9 Palu
}

\author{
Trisno, Yusuf Kendek dan Marungkil Pasaribu \\ e-mail: Trisno_Physics@yahoo.com \\ Program Studi Pend. Fisika, Jurusan Pendidikan MIPA, Universitas Tadulako \\ Jl. Soekarno Hatta KM. 9 Kampus Bumi Tadulako Tondo Palu - Sulawesi Tengah
}

\begin{abstract}
Abstrak - Penelitian ini bertujuan untuk menguji signifikansi perbedaan hasil belajar antara siswa yang mengikuti model pembelajaran Training Inquiry dengan pembelajaran konvensional pada pokok bahasan kalor siswa SMP Negeri 9 Palu. Penelitian ini menggunakan metode eksperimen semu (quasi experimental) dengan desain penelitian non equivalent control group design. Pengambilan sampel dilakukan secara purposive sampling. Sampel penelitian adalah kelas VII I sebagai kelas eksperimen dan kelas VII H sebagai kelas kontrol. Instrumen yang digunakan pada penelitian ini adalah tes hasil belajar dalam bentuk pilihan ganda. Hasil penelitian ini menunjukkan bahwa terdapat perbedaan hasil belajar antara siswa yang mengikuti model pembelajaran Training Inquiry dengan model pembelajaran konvensional pada pokok bahasan kalor siswa SMP Negeri 9 Palu yang ditunjukkan oleh uji hipotesis yang menggunakan uji-t dua pihak. Hasil perhitungan statistik diperoleh nilai thitung sebesar 4,28 dan tabel pada taraf signifikan $5 \%$ dan dk $=59$ adalah 2,001 sehingga thitung $>$ ttabel. Berdasarkan hasil uji hipotesis tersebut, maka dapat disimpulkan bahwa terdapat pengaruh model pembelajaran Training Inquiry terhadap hasil belajar pada pokok bahasan kalor siswa SMP Negeri 9 Palu.
\end{abstract}

Kata Kunci: Model Pembelajaran Training Inquiry, Hasil Belajar

\section{PENDAHULUAN}

Pembelajaran fisika yang merupakan salah satu unsur dalam Ilmu Pengetahuan Alam (IPA) memegang peranan penting dalam pengembangan ilmu pengetahuan dan teknologi. Oleh sebab itu pembelajaran fisika harus mendapat perhatian yang lebih mulai dari tingkat SD sampai perguruan tinggi. IPA fisika adalah ilmu pengetahuan yang menggunakan metode ilmiah dalam prosesnya. Dengan demikian maka proses pembelajaran fisika bukan hanya memahami konsep-konsep fisika semata, atau prinsip-prinsip saja tetapi juga merupakan suatu proses dalam penemuan. Sehingga pemahaman siswa terhadap hakikat fisika menjadi utuh, baik sebagai proses maupun sebagai produk.

Pembelajaran fisika yang harus diperhatikan adalah bagaimana siswa mendapat pengetahuan (learning to know), konsep dan teori melalui pengalaman praktis dengan cara melaksanakan observasi atau eksperimen (learning to do), secara langsung (skil objektivitas) sehingga dirinya berperan sebagai ilmuan.

Ada kesan yang kuat bahwa pelajaran fisika merupakan pelajaran yang sulit untuk dipahami dan kurang menarik. Salah satu penyebabnya adalah kurangnya kesempata siswa untuk mempelajari, mengamati, dan menemukan sendiri. Selain itu, ada beberapa faktor yang menyebabkan rendahnya hasil belajar fisika diantaranya proses pembelajaran yang ditemukan secara umum lebih menekankan pada pencapaian tuntutan kurikulum, dan sebagian guru belum menciptakan suasana pembelajaran yang menarik dan menyenangkan, sehingga siswa kurang termotivasi dan merasa terbebani dalam belajar fisika. Pembelajaran pun lebih bersifat teachercenterd guru hanya menyampaikan IPA sebagai produk dan siswa menghafal informasi faktual, serta kecenderungan penggunaan soal-soal bentuk pilihan ganda murni pada waktu ulangan harian maupun ulangan sumatif. Pembelajaran seperti itu akan menimbulkan ketidaktahuan pada diri siswa mengenai proses maupun sikap dari konsep fisika yang mereka peroleh. Dengan demikian, seorang pendidik perlu menerapkan suatu model pembelajaran yang dapat menarik minat siswa untuk mempelajari ilmu fisika. Model yang digunakan harus sesuai dengan tujuan pembelajaran serta jenis materi yang diajarkan. Kurang tepatnya menggunakan model pembelajaran, dapat menimbulkan kebosanan, monoton, atau bahkan siswa kesulitan dalam memahami konsep yang diajarkan.

Pembelajaran yang dapat membantu siswa memahami konsep-konsep fisika khususnya pada pokok bahasan kalor ini, diperlukan adanya suatu model yang dapat melibatkan 
ISSN 23383240

siswa secara optimal dalam pembelajaran. Model pembelajaran tersebut mempunyai andil yang cukup besar dalam kegiatan belajar mengajar. Salah satu model pembelajaran yang melibatkan keaktifan siswa untuk menemukan konsepnya sendiri adalah dengan model pembelajaran training inquiry. Model pembelajaran ini sangat cocok digunakan dalam pembelajaran IPA khususnya fisika dimana siswa terlibat langsung dengan objek yang dipelajarinya. Pembelajaran training inquiry yang melibatkan keaktifan siswa, siswa didorong untuk belajar aktif dengan konsepkonsep dan prinsip-prinsip untuk mereka sendiri. Di dalam model pembelajaran training inquiry terdapat lima tahapan, yaitu menghadapkan masalah, mengumpulkan informasi, mencari data dalam eksperimen, mengorganisasikannya, merumuskan, dan menjelaskan dan menganalisis proses penelitian merupakan metode yang baik dilakukan oleh guru ketika melaksanakan pembelajaran dikelas. Karena dengan menampilkan beberapa tahapan dalam pembelajaran inquiri siswa tidak hanya menghafalkan banyak rumus dan menghitung saja, tetapi juga menampilkan gejala-gejala fisika yang dapat mereka temui dalam kehidupan mereka sehari-hari sehingga mereka dapat memaknai konsep-konsep fisika yang diajarkan yang pada akhirnya dapat menciptakan proses pembelajaran fisika bermakna. Dari proses pembelajaran fisika yang bermakna inilah diharapkan dapat mempengaruhi hasil belajar siswa kelas VII SMP Negeri 9 Palu.

\section{METODOLOGI}

Penelitian ini menggunakan dua kelas dalam pengolahan datanya yaitu kelas VII H sebagai kelas kontrol dan kelas VII I sebagai kelas eksperimen. Pengolahan data pretest dilakukan dalam penelitian ini dengan tujuan untuk mengetahui keadaan awal kedua kelas. Sampel yang diambil harus dari kelas yang memiliki hasil belajar yang sama. Soal yang digunakan dalam pretest maupun postest berjumlah 34 soal berupa pilihan ganda yang telah divalidasi oleh validator ahli dan validasi item. Penskoran yang diberikan kepada siswa berdasarkan jawabannya jika menjawab benar diberi skor satu dan jika salah diberi skor nol. Sehingga dapat ditentukan rentangnya yaitu 0-34 berdasarkan jumlah soal.

Penelitian ini menggunakan metode kuasi eksperimen, dimana desain penelitian yang digunakan adalah "Non Equivalent Control Group Design" yang menggunakan dua kelompok subjek, satu diantaranya yang diberi perlakuan. Pengambilan sampel dalam penelitian ini menggunakan teknik purposive sampling, sampelnya diambil berdasarkan tujuan tertentu. Bentuk desainnya disajikan pada tabel I berikut:

TABEL I Desain PENeLITIAN
\begin{tabular}{|c|c|c|c|}
\hline Kelompok & Prates & Perlakuan & Pascates \\
\hline A (KE) & 0 & $\mathrm{X}_{1}$ & 0 \\
\hline B (KK) & 0 & $\mathrm{X}_{2}$ & 0 \\
\hline
\end{tabular}
(Nana Syaodih, 2009)

Keterangan:

A: Kelompok eksperimen
$\mathrm{B}:$ Kelompok kontrol
$\mathrm{X} 1:$ Model Training Inquiry
$\mathrm{X} 2:$ Model Konvensional
$\mathrm{O}:$ Tes awal (pretest)
$\mathrm{O}:$ Tes akhir (posttest)

\section{HASIL DAN PEMBAHASAN}

\subsection{Hasil Analisis Butir Soal}

Tes awal yang dilakukan pada kelas VII $\mathrm{H}$ dan kelas VII I menggunakan tes pilihan ganda yang dilakukan dua kali validasi yaitu yang pertama dilakukan validasi ahli oleh validator kemudian dilakukan validasi hitung setelah di uji cobakan pada siswa kelas VIII H SMP Negeri 9 Palu. Tes yang dibuat awalnya berjumlah 43 nomor soal, namun setelah dilakukan validasi oleh validator ahli ada tiga nomor soal yang dinyatakan tidak valid yaitu nomor 31, 32 dan 33. Data selengkapnya dapat dilihat pada lampiran 1.

Soal yang dinyatakan valid oleh validator ahli yaitu berjumlah empat puluh nomor soal di uji cobakan kepada siswa kelas VIII H dan dihitung validitasnya. Dari hasil validasi hitung diperoleh enam nomor soal dinyatakan tidak valid. Soal yang tidak valid ialah soal nomor $10,13,26$, 27, 30 dan 33. Dari hasil validasi dan validasi hitung diperoleh soal yang dinyatakan valid sebanyak tiga puluh empat nomor soal dan digunakan pada tes awal dan tes akhir untuk kelas VII $\mathrm{H}$ dan kelas VII I.

\subsubsection{Deskripsi Skor Pretest Kelas VII H}

Hasil tes awal yang dilakukan pada kelas VII $\mathrm{H}$ diperoleh nilai maksimum 12 dan nilai minimum 2. Pemberian skor berdasarkan jawaban jika menjawab benar diberi skor 1 dan salah diberi skor 0 . Jumlah skor atau nilai sisiwa yang diberikan berdasarkan rentangnya yaitu mulai dari 0 sampai 34 berdasarkan jumlah soal. Nilai rata-rata yang diperoleh 
kelas VII H yaitu sebesar 7,21 dan memiliki standar deviasi sebesar 3,33. Data selengkapnya dapat dilihat pada tabel I.

TABEL I. DESKRIPSI SKOR PRETEST KeLAS KONTROL

\begin{tabular}{|c|c|}
\hline Deskripsi & Hasil \\
\hline Jumlah Sampel & 31 \\
\hline Skor Maksimum & 12 \\
\hline Skor Minimum & 2 \\
\hline Skor Rata-rata & 7,21 \\
\hline Standar Deviasi & 3,33 \\
\hline
\end{tabular}

Skor pretest yang diperoleh kelas VII $\mathrm{H}$ dapat dibuatkan diagram batang frekuensi seperti terlihat pada gambar 1 .

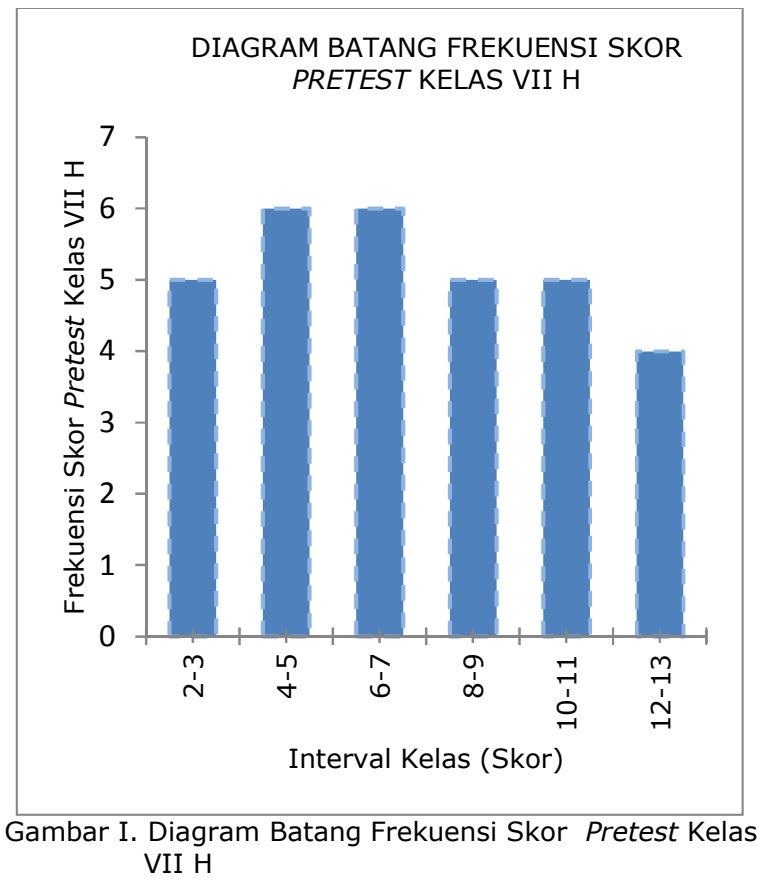

\subsubsection{Deskripsi Skor Pretest kelas VII I}

Hasil tes awal yang dilakukan pada kelas VII I diperoleh nilai maksimum 13 dan nilai minimum 2. Pemberian skor berdasarkan jawaban jika menjawab benar diberi skor 1 dan salah diberi skor 0 . Jumlah skor atau nilai sisiwa yang diberikan berdasarkan rentangnya yaitu mulai dari 0 sampai 34 berdasarkan jumlah soal. Nilai rata-rata yang diperoleh kelas VII I yaitu sebesar 7,70 dan memiliki standar deviasi sebesar 3,35.

TABEL II. DeSkripsi Skor PRETEST Kelas EKSPERIMen

\begin{tabular}{|c|c|}
\hline Deskripsi & Hasil \\
\hline Jumlah Sampel & 30 \\
\hline Skor Maksimum & 13 \\
\hline Skor Minimum & 2 \\
\hline Skor Rata-rata & 7,70 \\
\hline Standar Deviasi & 3,35 \\
\hline
\end{tabular}

Skor pretest yang diperoleh kelas VII I dapat dibuatkan diagram batang frekuensi seperti terlihat pada gambar II.

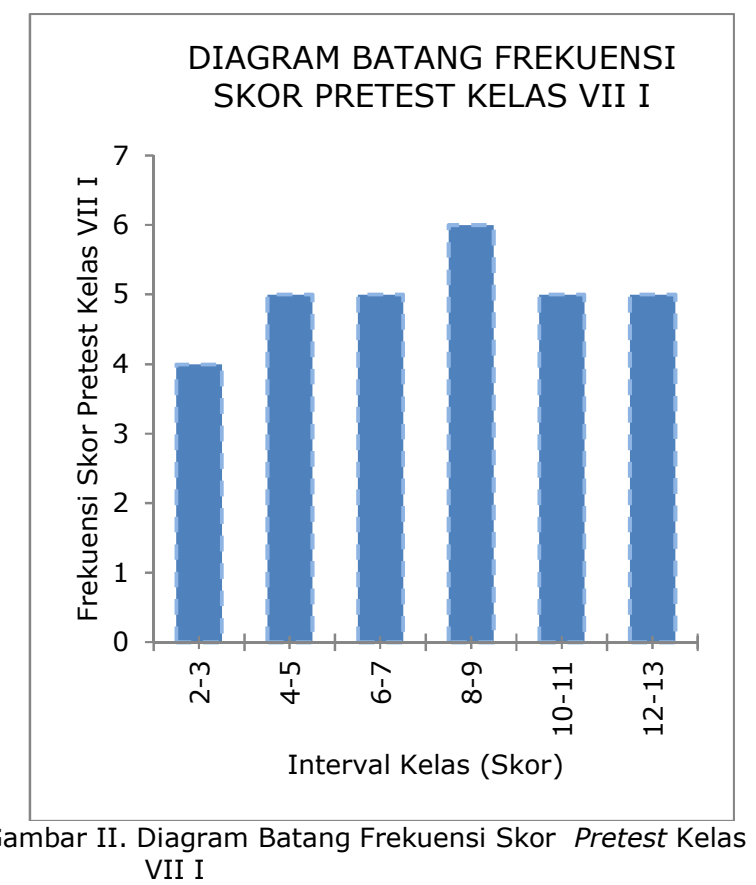

\subsection{Uji Normalitas Data}

Uji normalitas dilakukan dua kelas yaitu kelas eksperimen dan kelas kontrol untuk mengetahui apakah data pretes kelas ini berasal dari populasi yang berdistribusi normal atau tidak. Uji normalitas yang digunakan menggunakan persamaan Chi Kuadrat dengan $\mathrm{dk}=(6-3)=3$ dan taraf signifikansi 0,05. Adapun hipotesis dalam uji kenormalan data pretest adalah sebagai berikut :

$\mathrm{H}_{0}$ : sampel berasal dari populasi yang berdistribusi normal

$\mathrm{H}_{1}$ : $\quad$ sampel berasal dari populasi yang tidak berdistribusi normal

Kriteria pengambilan keputusannya adalah :

(1) Jika nilai signifikansi lebih kecil dari 0,05 maka $\mathrm{H}_{0}$ ditolak

(2) Jika nilai signifikansi lebih besar dari 0,05 maka $\mathrm{H}_{0}$ diterima

Setelah pengolahan data, diperoleh hasil seperti pada tabel III berikut.

TABEL III. HASIL UJI NORMALITAS Distribusi TES AWAL KELAS

\begin{tabular}{|c|c|c|c|}
\hline \multicolumn{3}{|c|}{ KONTROL DAN KELAS EKSPERIMEN } \\
\hline $\begin{array}{c}\text { Nilai X } \\
\text { Hitung }\end{array}$ & $\begin{array}{c}\text { Niali } \mathrm{X}^{2} \\
\text { Tabel }\end{array}$ & Keterangan \\
\hline $\begin{array}{l}\text { Kelas } \\
\text { VII H }\end{array}$ & 4,04 & 7,81 & $\begin{array}{c}\text { Berdistribusi } \\
\text { Normal }\end{array}$ \\
\hline $\begin{array}{c}\text { Kelas } \\
\text { VII I }\end{array}$ & 4,15 & 7,81 & $\begin{array}{c}\text { Berdistribusi } \\
\text { Normal }\end{array}$ \\
\hline
\end{tabular}

Berdasarkan hasil uji normalitas dengan menggunakan uji Chi kuadrat diperoleh nilai pretest untuk kelas eksperimen adalah 4,15 dan kelas kontrol adalah 4,04. Berdasarkan 
kriteria pengambilan keputusan maka $\mathrm{H}_{0}$ diterima atau data berdistribusi noramal. Hal ini berarti sampel dari kelas kontrol dan kelas eksperimen berasal dari populasi yang beristribusi normal. Data selengkapnya dapat dilihat pada lampiran perhitungan uji kenormalan.

\subsection{Uji Homogenitas Varians}

Uji homogenitas menggunakan persamaan uji Fisher (uji F) untuk mengetahui data berasal dari populasi yang sama. Seperti pada tabel IV yaitu hasil pengolahan data uji homogenitas.

tabel iV. hasil Uji Homogenitas Varians Tes Awal Kelas KONTROL DAN KELAS EKSPERIMEN

\begin{tabular}{|c|c|c|c|c|}
\hline Kelas & $\begin{array}{c}\text { Nilai } \\
\text { Varians }\end{array}$ & $\begin{array}{l}\text { Varians } \\
\text { Hitung }\end{array}$ & $\begin{array}{l}\text { Nilai F } \\
\text { Tabel }\end{array}$ & Keputusan \\
\hline $\begin{array}{l}\text { Kelas } \\
\text { VII H }\end{array}$ & 11,08 & \multirow{2}{*}{1,01} & \multirow[b]{2}{*}{1,85} & \multirow{2}{*}{$\begin{array}{c}\text { Kedua } \\
\text { Data } \\
\text { Homogen }\end{array}$} \\
\hline $\begin{array}{l}\text { Kelas } \\
\text { VII I }\end{array}$ & 11,2 & & & \\
\hline
\end{tabular}

Berdasarkan data hasil perhitungan uji homogenitas pada tabel IV diatas dapat disimpulkan bahwa nilai $F_{\text {hitung }}$ yang diperoleh sebesar 1,01 sedangkan nilai dari $F_{\text {tabel }}$ sebesar 1,85 . Hal ini menunjukkan nilai $F_{\text {hitung }}$ lebih kecil dari nilai $F_{\text {tabel }}$ yang berarti $\mathrm{H}_{0}$ diterima dengan kriteria bahwa tidak terdapat perbedaan varians antara kelas eksperimen dan kelas kontrol.

\subsection{Uji Beda Rata-rata Antara Kelas VII H dan Kelas VII I}

Uji beda rata-rata dilakukan dengan syarat bahwa data telah berdistribusi normal dan homogenitas. Uji beda ini menggunakan uji-t dua pihak dengan taraf signifikansi 0,05 . Oleh karena data telah berdistribusi normal dan telah homogenitas maka dilakukan uji hipotesis dengan hasil yang diperoleh seperti pada tabel $\checkmark$ dibawah ini.

tabel V. Hasil Uji-t Dua Pihak Tes Awal (PREtest) Kelas

\begin{tabular}{|l|c|c|c|c|}
\hline \multicolumn{1}{|c|}{ Kelas } & $\begin{array}{c}\text { Nilai } \\
\text { Rata- } \\
\text { rata }\end{array}$ & $\mathrm{t}$ hitung & $\mathrm{t}$ tabel & Keputusan \\
\hline $\begin{array}{l}\text { Kelas } \\
\text { VII H }\end{array}$ & 7,21 & 0,57 & 2,001 & $\mathrm{H}_{0}$ diterima \\
\cline { 1 - 2 } $\begin{array}{l}\text { Kelas } \\
\text { VII I }\end{array}$ & 7,70 & 0,57 & \\
\hline
\end{tabular}

Tabel V menunjukkan bahwa nilai thitung diperoleh sebesar 0,57 sedangkan nilai tabel sebesar 2,001. Hal ini menunjukkan bahwa nilai thitung lebih kecil dari nilai tabel yang berarti $\mathrm{H}_{0}$ diterima dan $\mathrm{H}_{1}$ ditolak. Ini menunjukkan bahwa tidak terdapat perbedaan hasil belajar antara kelas eksperimen dan kelas kontrol.

3.5 Analisis Hasil Posttest
Posttest dilaksanakan setelah kedua kelas diberikan perlakuan yaitu kelas eksperimen dengan model training inquiry dan kelas kontrol menggunakan model konvensional.

\subsubsection{Deskripsi Skor Posttest Kelas Kontrol}

Hasil tes akhir yang dilakukan pada kelas VII $\mathrm{H}$ diperoleh nilai maksimum 24 dan nilai minimum 13. Pemberian skor berdasarkan jawaban jika menjawab benar diberi skor 1 dan salah diberi skor 0 . Jumlah skor atau nilai siswa yang diberikan berdasarkan rentangnya yaitu mulai dari 0 sampai 34 berdasarkan jumlah soal. Nilai rata-rata yang diperoleh kelas VII H yaitu sebesar 18,08 dan memiliki standar deviasi sebesar 3,11.

TABEL VI. DESKRIPSI SKOR POSTTEST KeLAS KONTROL

\begin{tabular}{|c|c|}
\hline Deskripsi & Hasil \\
\hline Jumlah Sampel & 31 \\
\hline Skor Maksimum & 24 \\
\hline Skor Minimum & 13 \\
\hline Skor Rata-rata & 18,08 \\
\hline Standar Deviasi & 3,11 \\
\hline
\end{tabular}

Skor posttest yang diperoleh kelas kontrol dapat dibuatkan diagram batang frekuensi seperti terlihat pada gambar III.

DIAGRAM BATANG FREKUENSI SKOR POSTTEST KELAS KONTROL

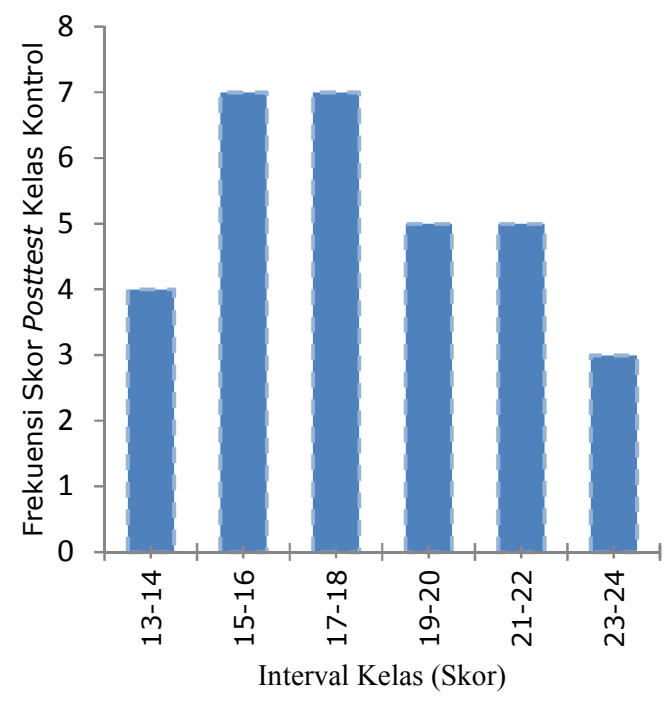

Gambar III. Diagram Batang Frekuensi Skor Posttest Kelas Kontrol

\subsubsection{Deskripsi Skor Posttest Kelas Eksperimen}

Hasil tes akhir yang dilakukan pada kelas VII I diperoleh nilai maksimum 29 dan nilai minimum 16. Pemberian skor berdasarkan jawaban jika menjawab benar diberi skor 1 dan salah diberi skor 0 . Jumlah skor atau nilai 
sisiwa yang diberikan berdasarkan rentangnya yaitu mulai dari 0 sampai 34 berdasarkan jumlah soal. Nilai rata-rata yang diperoleh kelas VII I yaitu sebesar 22,5 dan memiliki standar deviasi sebesar 4,15. Data selengkapnya dapat dilihat pada tabel 4.7 dan lampiran 17.

TABEL VII. DESKRIPSI SKOR POSTTSET KELAS EKSPERIMEN

\begin{tabular}{|c|c|}
\hline Deskripsi & Hasil \\
\hline Jumlah Sampel & 30 \\
\hline Skor Maksimum & 29 \\
\hline Skor Minimum & 16 \\
\hline Skor Rata-rata & 22,5 \\
\hline Standar Deviasi & 4,15 \\
\hline
\end{tabular}

Skor posttest yang diperoleh kelas eksperimen dapat dibuatkan kurva frekuensi seperti terlihat pada gambar IV.

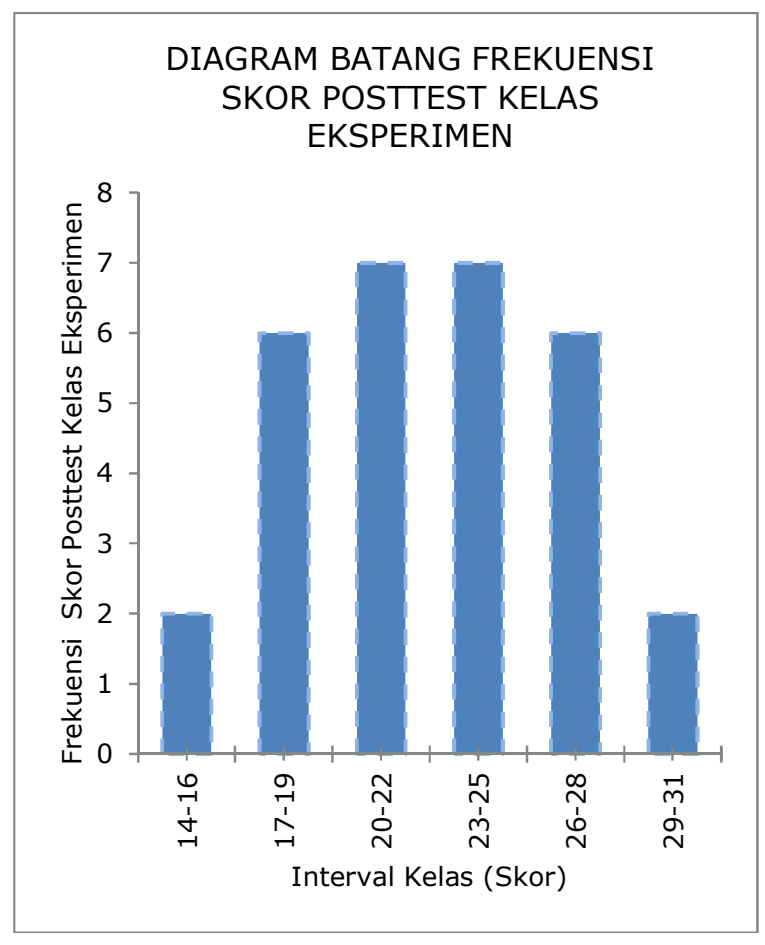

Gambar IV. Diagram Batang Frekuensi Skor Posttest Kelas Eksperimen

\subsection{Uji Hipotesis}

Uji hipotesis ini menggunakan uji-t dua pihak dengan tujuan untuk mengetahui hipotesis penelitian diterima atau ditolak. Uji-t dua pihak menggunakan taraf signifikansi 0,05 dan $\mathrm{dk}=$ $\mathrm{n}_{1}+\mathrm{n}_{2}-2$ atau $\mathrm{dk}=59$. Skor rata-rata kelas kontrol diperoleh yaitu sebesar 18,08 dan skor rata-rata kelas eksperimen diperoleh yaitu sebesar 22,50. Standar deviasi yang diperoleh pada kelas kontrol yaitu sebesar 3,11 dan kelas eksperimen yaitu sebesar 4,15. Setelah dilakukan pengolahan data maka diperoleh hasil yang dapat dilihat pada tabel 4.8.
ISSN 23383240

TABEL VIII. UJI HIPOTESIS TES AKHIR (POSTTEST) KELAS

\begin{tabular}{|c|c|c|c|c|}
\hline Kelas & $\begin{array}{c}\text { Skor } \\
\text { Rata- } \\
\text { rata }\end{array}$ & $\mathrm{t}$ hitung & $\mathrm{t}$ tabel & Keputusan \\
\hline $\begin{array}{l}\text { Kelas VII H } \\
\text { (Kontrol) }\end{array}$ & 18,08 & 4,72 & 2,001 & $\begin{array}{c}\mathrm{H}_{1} \\
\text { diterima }\end{array}$ \\
\hline $\begin{array}{l}\text { Kelas VII I } \\
\text { (Eksperimen) }\end{array}$ & 22,50 & $4,5)$ & \\
\hline
\end{tabular}

Tabel VIII diatas menunjukkan bahwa nilai thitung diperoleh sebesar 4,72 sedangkan nilai $t_{\text {tabel }}$ sebesar 2,001. Hal ini menunjukkan bahwa nilai thitung lebih besar dari nilai tabel yang berarti bahwa $\mathrm{H}_{1}$ diterima dan $\mathrm{H}_{0}$ ditolak. Sehingga penelitian ini menunjukkan bahwa terdapat perbedaan hasil belajar antara siswa yang mengikuti model pembelajaran training inquiry dengan siswa yang mengikuti model pembelajaran konvensional.

\subsection{Pembahasan}

Tes awal (pretest) dilakukan pada kedua kelas untuk mengetahui keadaan awal kedua kelas sebelum diberi perlakuan. Hasil tes awal untuk kedua kelas yang diperoleh yaitu menunjukkan bahwa tidak terdapat perbedaan hasil belajar antara siswa yang mengikuti model pembelajaran training inquiry dengan model pembelajaran konvensional. Hal ini dibuktikan dengan menggunakan uji hipotesis. Pada hasil pengujiannya diperoleh nilai thitung sebesar 0,57 dan nilai tabel pada taraf signifikan $(a=0,05)$ sebesar 2,001 yang berarti nilai $t$ berada pada daerah penerimaan $\mathrm{H}_{0}$ yaitu $-\mathrm{t}_{(1-}$ $1 / 2 a)<t<t_{(1-1 / 2 a)}$ sehingga $H_{1}$ ditolak dan $\mathrm{H}_{0}$ diterima. Dari hasil pretest yang diperoleh menunjukkan bahwa hasil belajar siswa pada kelas VII H dan kelas VII I sama. Sehingga kedua kelas dapat dijadikan sampel pada penelitian.

Kelas yang dijadikan sampel memiliki hasil belajar yang sama sebelum diberi perlakuan. Proses pembelajaran dilakukan didalam kelas sebanyak empat kali pertemuan dengan masing-masing model pembelajaran yang berbeda pada kedua kelas. Dipertemuan akhir dilakukan tes akhir (posttest) untuk mengetahui apakah terdapat perbedaan hasil belajar antara siswa yang mengikuti model pembelajaran training inquiry dengan model pembelajaran konvensional pada siswa SMP Negeri 9 Palu.

Hasil uji hipotesis posttest menggunakan uji-t dua pihak diperoleh yaitu nilai thitung sebesar 4,72 sedangkan nilai tabel pada taraf signifikan $(\mathrm{a}=0,05)$ dan $\mathrm{dk}=\mathrm{n} 1+\mathrm{n} 2-2$ diperoleh sebesar 2,001. Hal ini menunjukkan bahwa nilai thitung lebih besar dari nilai tabel. Berdasarkan syarat 
bahwa $\mathrm{H}_{0}$ diterima jika $\mathrm{t}_{(1-1 / 2 \mathrm{a})}<\mathrm{t}<\mathrm{t}_{(1-1 / 2 \mathrm{a})}$ sehingga thitung berada diluar penerimaan $\mathrm{H}_{0}$ dan berada pada penerimaan $\mathrm{H}_{1}$ atau $\mathrm{H}_{0}$ ditolak dan $\mathrm{H}_{1}$ diterima. Maka dapat dinyatakan bahwa terdapat perbedaan hasil belajar antara siswa yang mengikuti model pembelajaran training inquiry dengan model pembelajaran konvensional pada siswa SMP Negeri 9 Palu.

Hasil uji hipotesis posttest menunjukkan bahwa model pembelajaran training inquiry memilki hasil belajar yang lebih baik dibandingkan dengan model pembelajaran konvensional. Selain itu dapat pula dilihat dari nilai rata-rata siswa pada kedua kelas yang menunjukkan nilai rata-rata pada kelas eksperimen lebih besar dari nilai rata-rata pada kelas kontrol yaitu pada kelas eksperimen diperoleh nilai rata-rata sebesar 22,50 sedangkan pada kelas kontrol diperoleh nilai rata-rata sebesar 18,08 . Dari perbedaan hasil belajar ini dapat dilihat pengaruh model pembelajaran training inquiry pada kelas eksperimen sangat baik.

Perbedaan hasil belajar pada kedua kelas terjadi karena model pembelajaran yang diberikan antara kelas eksperimen dan kelas kontrol itu berbeda. Pada kelas eksperimen memiliki hasil belajar yang lebih baik dibanding dengan kelas kontrol karena kelas eksperimen menggunakan model pembelajaran training inquiry yang menuntut siswa lebih aktif dalam tahap pembelajarannya. Sedangkan pada kelas kontrol menggunakan model pembelajaran konvensional yang identik dengan metode ceramah sehinggah siswa lebih pasif dan guru yang lebih aktif.

Kelas eksperimen menggunakan model pembelajaran training inquiry yang dapat menguntungkan karena memberi peluang sama kepada semua siswa, baik siswa yang memiliki kemampuan rendah, sedang mupun tinggi untuk berhasil. Oleh karena itu, siswa yang berkemampuan rendah, sedang maupun tinggi ditantang untuk dapat menemukan materi melalui praktikum. Dengan model pembelajaran training inquiry siswa lebih berani berbicara didepan kelas. Pada saat pembelajaran yang dilaksanakan di SMP Negeri 9 Palu semua siswa aktif dalam bereksperimen untuk memecahkan masalah mengenai materi kalor. Salah satu contoh saat siswa diberikan masalah mengenai materi kalor tentang pengaruh kalor terhadap perubahan suhu siswa secara berkelompok dan berkerjasama melakukan eksperimen menyelidiki bagaimana kalor dalam mengubah suhu suatu zat. Hal inilah yang menyebabkan model pembelajaran training inquiry memiliki hasil belajar yang lebih baik dari pada model
ISSN 23383240

pembelajaran konvensional. Hal ini didukung oleh hasil penelitian dari Ratni Sirait (2012).

Model pembelajaran training inquiry menuntut siswa untuk memecahkan sebuah fenomena dalam fisika dengan melakukan eksperimen sehingga siswa lebih aktif dibanding guru. Adapun langkah-langkah dari model pembelajaran training inquiry menurut Bruce Joice 1996 (dalam Nurhayati, 2006) yaitu (1) diajukan kepada siswa suatu masalah atau fenomena fisika melalui kegiatan demonstrasi, (2) berdasarkan kegiatan demonstrasi, siswa berusaha untuk mengumpulkan data informasi sebanyak-banyaknya tentang masalah yang mereka hadapi, (3) siswa melakukan isolasi terhadap data-data yang menjadi pokok masalah yang dihadapi, (4) guru dapat merumuskan penjelasan untuk membimbing siswa pada pemecahan masalah yang terarah, dan tahap terakhir (5) siswa menarik kesimpulan mengenai fenomena fisika sekaligus menilai hipotesis atau bahkan membuat hipotesis baru yang relevan. Lima tahap pembelajaran training inquiry memberikan pengaruh pada hasil belajar siswa pada kelas eksperimen.

Kelas kontrol menggunakan model pembelajaran konvensional yang merupakan model pembelajaran yang sering kita jumpai disekolah-sekolah. Model pembelajaran yang digunakan ialah model pembelajaran direct intraction (pembelajaran langsung) yang menuntut guru lebih aktif dibanding dengan siswa. Hal inilah yang kadang membuat siswa cepat bosan dalam belajar. Model pembelajaran konvensional menuntut guru yang lebih aktif dari pada siswa sehingga siswa lebih banyak diam dan mendengar.

\section{KESIMPULAN}

Data hasil posttest yang diperoleh yaitu skor rata-rata kelas kontrol adalah sebesar 18,08 dan kelas eksperimen adalah sebesar 22,50. Standar deviasi yang diperoleh ialah kelas kontrol sebesar 3,11 dan kelas eksperimen sebesar 4,15. Hasil uji statisitik posttest yang diperoleh yaitu nilai thitung sebesar 4,72 lebih besar dari nilai tabel pada taraf signifikan ( $a=$ $0,05)$ dan $d k=59$ yaitu sebesar 2,001. Hal ini menunjukkan bahwa thitung berada pada daerah penolakan $\mathrm{H}_{0}$, yakni $\mathrm{H}_{0}$ diterima jika $\left.-\mathrm{t}_{(1-1 / 2 a}\right)<$ $\mathrm{t}<\mathrm{t}_{(1-1 / 2 \mathrm{a})}$ atau penelitian ini menunjukkan bahwa hipotesis $\left(\mathrm{H}_{0}\right)$ ditolak dan hipotesis penelitian $\left(\mathrm{H}_{1}\right)$ diterima. Sehingga dapat dinyatakan bahwa terdapat perbedaan hasil belajar antara siswa yang mengikuti model pembelajaran training inquiry dengan siswa 
yang mengikuti model pembelajaran konvensional.

\section{PUSTAKA RUJUKAN}

[1] Arikunto, Suharsimi. (2013). Dasar-Dasar Evaluasi Pendidikan. Jakarta: PT Bumi Aksara.

[2] Mulyani, Euis. (2003). Pengaruh Model Pembelajaran Inkuiri Terhadap Hasil Belajar Siswa, (online), (http://file.upi.edu/fmipa.html, diakses 22 Juni 2013).

[3] Munaf, Syambasri. (2003). Evaluasi Pendidikan Fisika, (online), (http://zaifbio.wordpress.com /2009/01/30/ hasil belajar-2, diakses 2 Juli 2013).

[4] Nurhayati, Novi (2006). Pengembangan Model Pembelajaran Inkuiri Jenis Training Inquiry untuk Meningkatkan Kemampuan Berhipotesis Siswa dalam Pembelajaran Fisika di SMP. Skripsi Tidak Diterbitkan. Bandung: Universitas Pendidikan Indonesia.

[5] Syaodih, Nana. (2009). Metode Penelitian Pendidikan Edisi ke-5. Bandung: PT Remaja Rosdakarya. 